Magdalena Satora

Department of Packaging Science, Cracow University of Economics

e-mail: magdalena.satora@uek.krakow.pl

Teresa Gajewska

Institute of Rail Vahicles, Cracow University of Technology

e-mail: teresa.gaiewska@mech.pk.edu.pl

Maciej Szkoda

Institute of Rail Vahicles, Cracow University of Technology

e-mail: maciei.szkoda@mech.pk.edu.pl

\title{
ANALYSIS OF SELECTED FACTORS INFLUENCING THE IRREGULARITY OF DELIVERIES OF FRUIT AND VEGETABLES
}

\begin{abstract}
Background: The chapter is devoted to the issue of the irregularity of the deliveries of fresh fruit and vegetables. Occurrence of any disruptions in the company's operations may have a negative impact on its effectiveness. The aim of the chapter is to analyze the selected factors affecting the occurrence of this type of problem and to propose actions to reduce its scale.

Methods: The problem of irregularities in the supply of fresh fruit and vegetables is presented on the example of the company in which the occurrence of this problem was detected. The company provides services in the field of international road refrigerated transport. In order to determine the factors affecting the irregularity of deliveries, data from six consecutive months (May-October period) in years 2017-18 were analyzed. These data related to, i.a., the number of deliveries of individual fruit and vegetables and their countries of origin.

Results: On the basis of the data analysis, it was determined that one of the main factors affecting the irregularity of deliveries of fresh fruit and vegetables may be the seasonality of their supply.

Conclusions: The seasonal nature of the supply of fresh fruit and vegetables is a real challenge for companies that deal with their delivery. In the case of enterprises whose activity is focused primarily on the international transport of this type of products, the key is to look for new producers or expand their activities to the domestic country, in order to limit the impact of seasonality on the number of deliveries.
\end{abstract}


Keywords: delivery of fresh fruit and vegetables, irregularity of deliveries, seasonality of supply, seasonality of demand, refrigerated transport

\section{INTRODUCTION}

Refrigerated transport of food products (Cold Chain) is one of the most important types of transport, bearing in mind that it is mainly the transport of food products needed for the life and proper functioning of every human being [Gajewska and Lorenc 2019]. Transport and storage of food, as well as timely delivery to consumers, is important in order to prolong the availability of perishable products and secure the procurement of food. The length of time that food remains edible and nutritious depends on temperature, moisture, and other factors that affect the growth rates of organisms that cause spoilage (on the natural physiological sentences of the product in the case of living products such as fruits and vegetables) [Tanner 2016]. Food products, including fresh fruit and vegetables, require special treatment during transport because they are consumed by humans. It should be avoided that during transport, contamination of fruit and vegetables would get into the transport, which could affect the quality of transported goods or even be a source of health hazard for potential consumers [Leleń 2015, Satora and Szkoda 2019]. The transport of fresh fruit and vegetables is a technical challenge, as these products are living organisms, both during the vegetation period and after harvest, in which physiological processes are constantly taking place, which cause their ripening and aging [Górecka-Orzechowska and Raczek 2012]. Thanks to the use of various types of cooling equipment, fresh fruit and vegetables, kept at a low temperature, can be transported in the cold chain, even over long distances: by land, sea and air. The conditions of transport of goods requiring transport at controlled temperature, including fresh fruit and vegetables, are regulated in the agreement on international transport of perishable foodstuffs and special means of transport intended for such transport, called the ATP agreement [ATP].

An important aspect of the supply of fresh fruit and vegetables is the increased number of products on the market during the summer period. This implies the need to transport and store a larger quantity of raw material during this period. Fruit and vegetables should be delivered to the warehouse as soon as possible after harvest so that the ripening process does not start [Baran and Sint 2014].

The chapter is devoted to the issue of the irregularity of the deliveries of fresh fruit and vegetables. Occurrence of any disruptions in the company's operations may have a negative 
impact on its effectiveness. The aim of the chapter is to analyze the selected factors affecting the occurrence of this type of problem and to propose actions to reduce its scale. One of the basic factors in the supply of fresh fruit and vegetables is the problem of seasonality. Seasonality of fruit and vegetables supply is very important for enterprises specializing in the processing of these raw materials. J. Gajda defines seasonality as follows: "It is the occurrence of annual recurring regular fluctuations in the intensity of economic activity as a result of changes in the conditions of production and consumption caused by successive seasons" [Sobczyk 1976].

\section{TRANSPORT OF FRUIT AND VEGETABLES}

The cold chain is a term applied to food handling and distribution where the product is maintained at suitable conditions all the way from the cooling of the freezing process to the point of sale. This requires transport, various kinds of storage and display [Gajewska and Grigoroudis 2017].

The transport of fresh soft fruits is a particularly complex task and depends on their assortment. The specificity of strawberries is that they are very delicate, sensitive to crushing and perishable (when stored in improper conditions, they mould quickly). In view of these characteristics, it should be transported in small containers (lupins) with a capacity of approximately $2 \mathrm{~kg}$. Nowadays, instead of the previously used lupines made of wood plywood, plastic lupines are used, as they are durable and easy to clean (they can be washed many times with water and a commercially available detergent) [Kuziemska et al. 2016]. The time of day and duration of transport play a very important role in the transport of soft fruits. Fruit should not be transported during hot weather, especially over long distances. However, if necessary (this applies to the transport of soft fruits for direct consumption), specialist vehicles should be used. In order to move the fruit from the collection point to the processing plant, transport is usually carried out in the afternoon or at night due to lower temperatures at this time of day and because during the day the fruit is harvested and delivered to the collection point [Marczuk 2012]. When transporting fruit, it is very important to ensure the right climatic conditions, especially to maintain the right temperature, depending on whether we transport fresh, frozen, dried or canned products. In any case, an increase in temperature during transport will accelerate many unfavourable quality changes, such as microbiological spoilage, non-enzymatic browning, oxidation of fats and a decline in nutritional value, which may render the fruit unusable both for processing and for direct consumption. 
The facilities used to transport fresh fruit and vegetables, including cold stores, containers and specialised transport trailers, must meet certain conditions. It is only by meeting the technical requirements of the ATP contract and, most importantly, by choosing the right storage temperature for the transported products and then maintaining this temperature throughout the cold chain that additional benefits can be gained from the use of controlled atmosphere technology. For this purpose, typical facilities used in the transport of fresh fruit and vegetables must be specially adapted (above all airtight) and equipped with equipment to create and maintain the atmosphere [Górecka-Orzechowska and Raczek 2012].

\section{MATERIAL AND METHODS}

In the chapter, the problem of the irregularity of deliveries of fruit and vegetables on the example of a selected company was examined. The company specializes in international road transport of fresh fruit and vegetables, such as watermelons, grapes, lemons, cucumbers, peppers or tomatoes. The company's essence is the wholesale supply of products not only in Poland or the European Union, but all over the world. The analysis of selected factors affecting delivery irregularities was carried out based on the created procedure, which is presented in Figure 1.

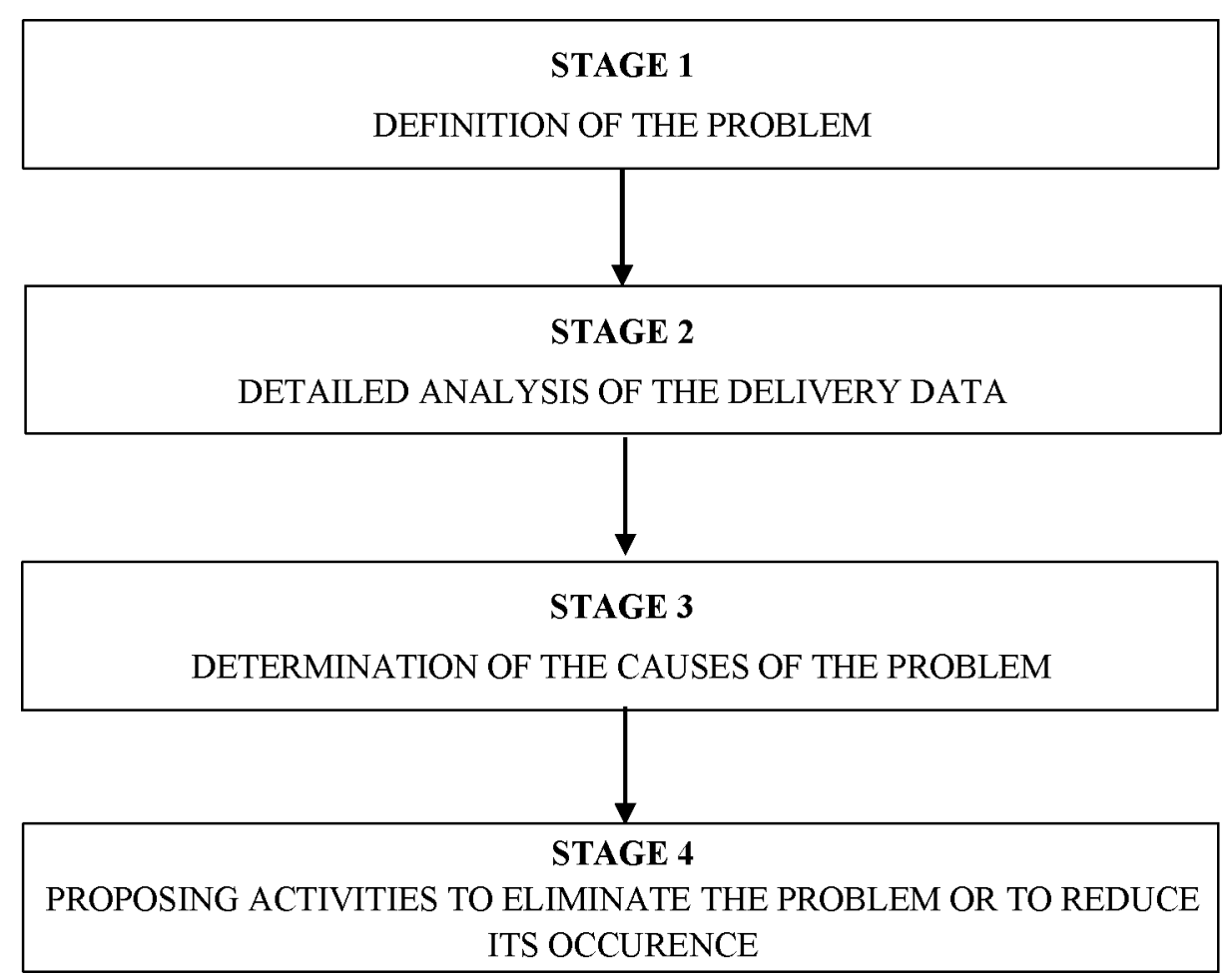


Fig. 1. Procedure for the analysis of the problem of the irregularity of deliveries Source: own work

The process of analyzing selected factors affecting the irregularity of supply of fresh fruit and vegetables begins with defining the problem. Next, a detailed analysis of the data on deliveries carried out by the company is required to isolate the causes causing the problem, and then determine if and what actions can be taken to reduce or eliminate their effects. It is important to choose the appropriate period of time for the analysis.

In the analysis, the data on the number of deliveries of individual fruit and vegetables and their countries of origin in May-October in two consecutive years (2017-2018) was used. The focus was on the analysis of data on imports of products from various countries, as this is mainly the specifics of the enterprise being the subject of the study. Data from the May-October period was taken into consideration, because the company makes the most deliveries in these months and the problem of the irregularity of deliveries of fresh fruit and vegetables is clearly visible during this period.

\section{RESULTS AND DISCUSSION}

In this chapter, the results of the analysis of selected factors affecting the irregular deliveries of fresh fruit and vegetables were presented. The analysis was carried out on the basis of the procedure presented in Figure 1.

The first step was to define the problem the company is facing. For this purpose, data on the total number of deliveries carried out in the May-October period were analyzed. Data from two successive years (2017 and 2018) were compared in order to determine whether the problem occurred once or if it occurs more frequently (Figures 2 and 3).

A. Kolinski et al. (eds.), Contemporary challenges in supply chains, Vol. 1, https://doi.org/10.17270/B.M.978-83-66017-88-7.11 


\section{NUMBER OF DELIVERIES IN 2017}

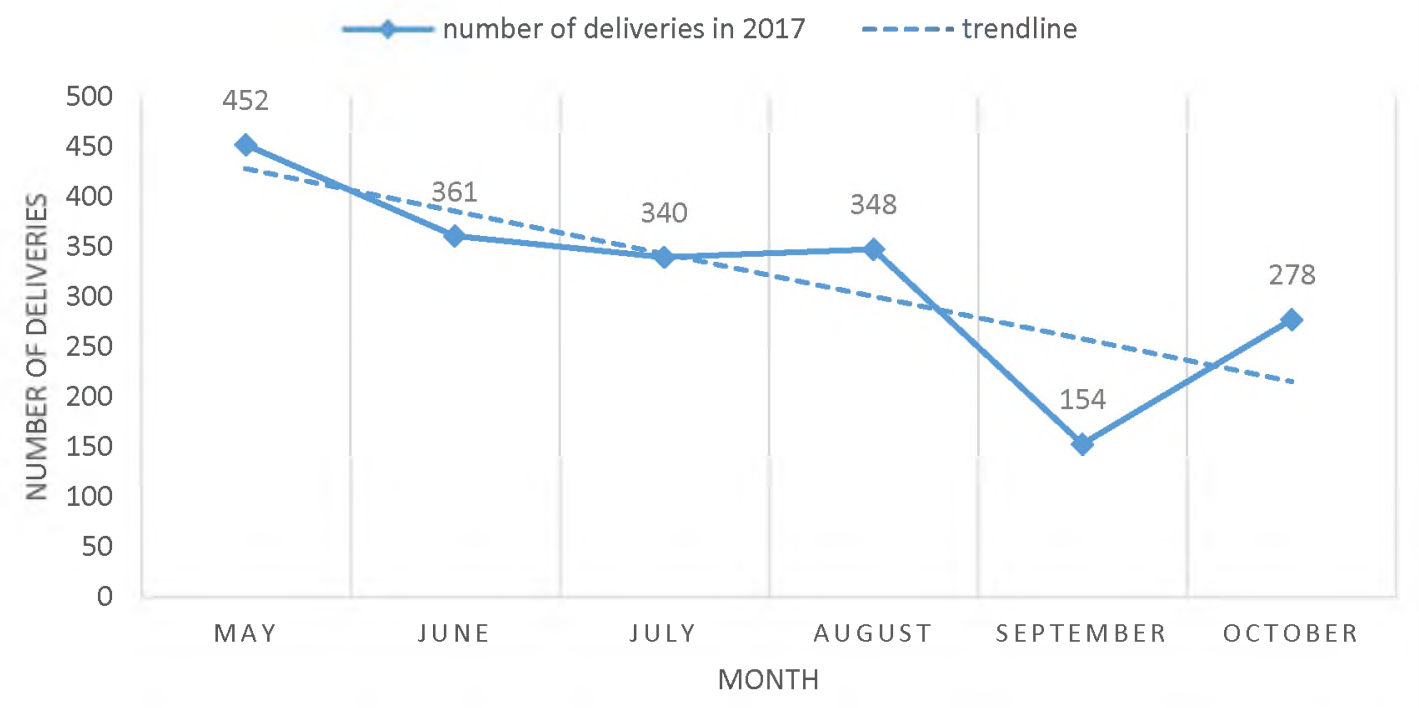

Fig. 2. The number of deliveries in the May-October 2017 period

Source: own work

\section{NUMBER OF DELIVERIES IN 2018}

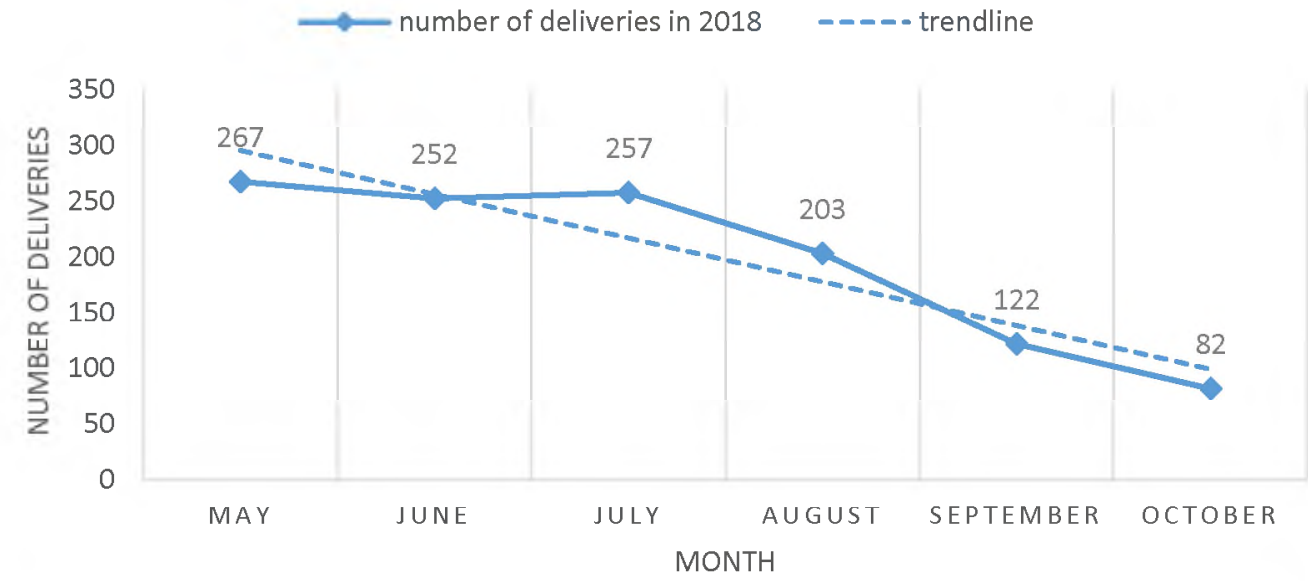

Fig. 3. The number of deliveries in the May-October 2018 period Source: own work

The data presented in Figures 2 and 3 illustrate the problem occurring in the surveyed enterprise. It can be said that the number of deliveries varies from one month to another and this regularity can be seen in both 2017 and 2018. In both cases, the largest number of deliveries is in May, while the least deliveries are made in September and October. 
Figure 4 presents a summary of the number of deliveries for the first half of 2017 and 2018 together with the values forecasted for the next half of the year. By approximating the data for 2017 , it may be assumed that in the second half of the year the number of deliveries should remain at the level of around 300. According to the forecasts, the upward trend is noticeable in the spring season, i.e. at the turn of February and March 2017.

Analysing the forecasts of deliveries in the second half of 2018, a gradual decrease to the level of 100 deliveries at the end of March is expected. This situation could have been caused by unfavourable weather conditions, which could significantly affect the reduction of the number of deliveries in 2018 .

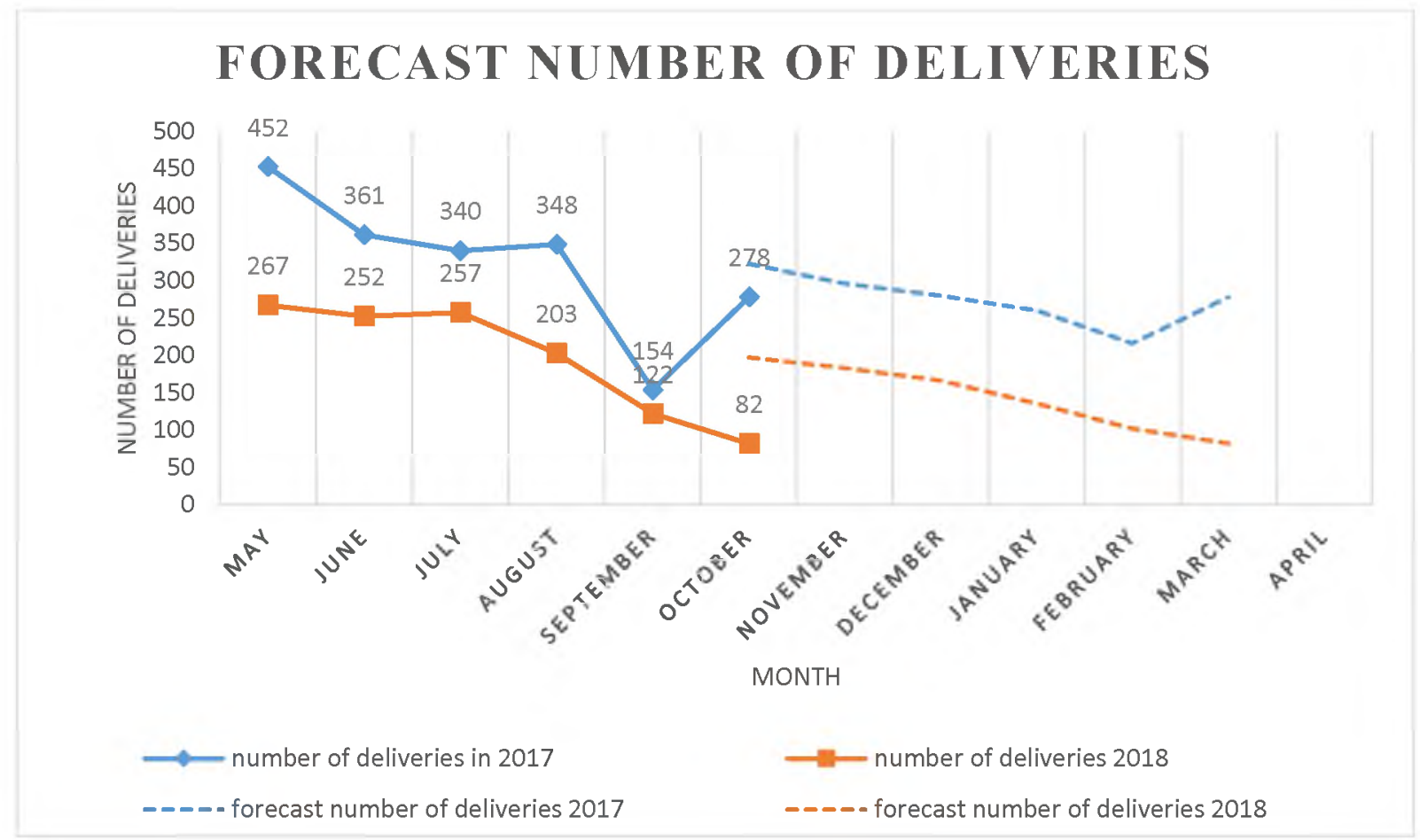

Fig. 4. The forecast number of deliveries in the May-October 2017 and 2018 period

Source: own work

In order to determine the factors affecting the differences in the number of deliveries in individual months, it was necessary to conduct a detailed analysis of delivery data. Information such as the number of deliveries from individual countries and the number of deliveries of the most commonly transported fruit and vegetables were taken into account. Table 1 shows the number of deliveries from individual countries in the period May-October in the years 2017-2018. 
Table 1. The number of deliveries from particular countries in the period May-October in years 2017-18

\begin{tabular}{|c|c|c|c|c|c|c|c|c|c|c|c|c|c|c|}
\hline \multirow[b]{3}{*}{$\begin{array}{c}\text { Country of } \\
\text { origin }\end{array}$} & \multicolumn{14}{|c|}{ Number of deliveries } \\
\hline & \multicolumn{7}{|c|}{ year 2017} & \multicolumn{7}{|c|}{ year 2018} \\
\hline & $\stackrel{\Xi}{\Sigma}$ & 莺 & 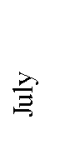 & 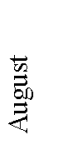 & 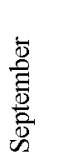 & $\begin{array}{l}\overline{0} \\
\frac{0}{0} \\
\frac{0}{5}\end{array}$ & $\sum_{\bar{\sigma}}$ & 急 & $\cong$ & 宔 & 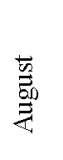 & 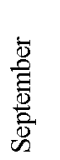 & $\begin{array}{l}\frac{\overline{0}}{0} \\
\frac{0}{0}\end{array}$ & $\sum_{\bar{\sigma}}$ \\
\hline $\begin{array}{l}\text { The } \\
\text { Netherlands }\end{array}$ & 208 & 128 & 80 & 36 & 0 & 0 & 452 & 89 & 93 & 61 & 26 & 30 & 14 & 313 \\
\hline Spain & 152 & 98 & 78 & 87 & 47 & 30 & 492 & 69 & 42 & 39 & 36 & 20 & 25 & 231 \\
\hline Italy & 52 & 70 & 67 & 65 & 51 & 124 & 429 & 41 & 40 & 60 & 85 & 57 & 14 & 297 \\
\hline Belgium & 23 & 16 & 26 & 12 & 0 & 45 & 122 & 0 & 4 & 2 & 0 & 0 & 0 & 6 \\
\hline Greece & 10 & 26 & 28 & 25 & 0 & 1 & 90 & 8 & 22 & 33 & 23 & 0 & 0 & 86 \\
\hline Turkey & 6 & 16 & 0 & 42 & 2 & 0 & 66 & 22 & 5 & 10 & 26 & 11 & 12 & 86 \\
\hline Germany & 1 & 0 & 0 & 0 & 0 & 0 & 1 & 3 & 0 & 2 & 5 & 3 & 1 & 4 \\
\hline Hungary & 0 & 5 & 59 & 80 & 0 & 0 & 144 & 0 & 7 & 50 & 0 & 0 & 0 & 57 \\
\hline France & 0 & 2 & 2 & 0 & 0 & 0 & 4 & 20 & 9 & 0 & 1 & 1 & 11 & 42 \\
\hline Slovenia & 0 & 0 & 0 & 1 & 40 & 44 & 85 & 7 & 23 & 0 & 1 & 0 & 4 & 35 \\
\hline Portugal & 0 & 0 & 0 & 0 & 14 & 34 & 48 & 2 & 1 & 0 & 0 & 0 & 0 & 3 \\
\hline England & 0 & 0 & 0 & 0 & 0 & 0 & 0 & 6 & 6 & 0 & 0 & 0 & 1 & 13 \\
\hline SUM & 452 & 361 & 340 & 348 & 154 & 278 & & 267 & 252 & 257 & 203 & 122 & 82 & \\
\hline
\end{tabular}

Source: own work

Based on Table 1, it can be stated that the most deliveries, both in the year 2017 and 2018 , were made from countries such as the Netherlands, Spain and Italy (respectively 765, 723 and 726 deliveries in both analyzed periods in total). It can also be seen that in individual months there are deviations in their number. For some countries, there are less significant changes and products are imported throughout the period under analysis (e.g. Spain and Italy), while for others 
these changes are significant and there are also the months in which deliveries are not carried out at all (e.g. Greece, Turkey)

To determine the cause of such a phenomenon, it is also necessary to analyze data on the deliveries of individual products during the considered period of time, because they are closely connected with the countries of origin. These data are summarized in Table 2

Table 2. The number of deliveries of the particular fruit and vegetables in the May-October 2017 and May-October 2018 periods

\begin{tabular}{|c|c|c|c|c|c|c|c|c|c|c|c|c|c|c|}
\hline \multirow[b]{3}{*}{$\begin{array}{c}\text { Fruit/ } \\
\text { vegetable }\end{array}$} & \multicolumn{14}{|c|}{ Number of deliveries } \\
\hline & \multicolumn{7}{|c|}{ year 2017} & \multicolumn{7}{|c|}{ year 2018} \\
\hline & 怘 & $\stackrel{\Xi}{\Xi}$ & $\stackrel{2}{\Xi}$ & 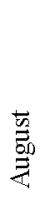 & 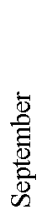 & $\frac{\overline{0}}{\frac{8}{8}}$ & $\sum_{\bar{\sigma}}$ & 密 & $\stackrel{\Xi}{\Xi}$ & 莺 & 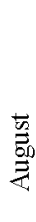 &  & $\begin{array}{l}\frac{10}{0} \\
\frac{8}{8}\end{array}$ & $\sum_{\sigma}$ \\
\hline pepper & 58 & 32 & 23 & 0 & 0 & 30 & 143 & 22 & 0 & 0 & 0 & 0 & 0 & 22 \\
\hline watermelon & 55 & 41 & 59 & 83 & 0 & 0 & 238 & 25 & 17 & 87 & 20 & 0 & 0 & 149 \\
\hline peach & 48 & 34 & 66 & 45 & 27 & 0 & 220 & 0 & 17 & 42 & 43 & 7 & 0 & 109 \\
\hline cucumber & 38 & 0 & 0 & 0 & 15 & 35 & 88 & 0 & 0 & 0 & 0 & 0 & 7 & 7 \\
\hline carrot & 33 & 41 & 0 & 0 & 0 & 0 & 74 & 24 & 44 & 0 & 0 & 0 & 0 & 68 \\
\hline tomato & 29 & 41 & 43 & 0 & 11 & 0 & 124 & 32 & 38 & 39 & 0 & 0 & 0 & 109 \\
\hline nectarine & 19 & 61 & 61 & 0 & 20 & 0 & 161 & 0 & 20 & 33 & 23 & 0 & 0 & 76 \\
\hline lemon & 17 & 17 & 26 & 11 & 25 & 0 & 96 & 16 & 0 & 9 & 0 & 18 & 10 & 53 \\
\hline grape & 0 & 0 & 49 & 51 & 55 & 54 & 209 & 0 & 21 & 37 & 35 & 59 & 15 & 167 \\
\hline grapefruit & 0 & 0 & 0 & 9 & 0 & 22 & 31 & 0 & 0 & 0 & 0 & 7 & 9 & 16 \\
\hline orange & 0 & 0 & 0 & 7 & 0 & 32 & 39 & 0 & 0 & 0 & 0 & 0 & 13 & 13 \\
\hline broccoli & 0 & 0 & 0 & 0 & 12 & 0 & 12 & 12 & 0 & 0 & 0 & 0 & 0 & 12 \\
\hline mandarin & 0 & 0 & 0 & 0 & 0 & 38 & 38 & 0 & 0 & 0 & 0 & 0 & 8 & 8 \\
\hline potato & 0 & 0 & 0 & 0 & 0 & 0 & 0 & 5 & 0 & 0 & 0 & 0 & 0 & 45 \\
\hline cauliflower & 0 & 0 & 0 & 0 & 0 & 0 & $\mathbf{0}$ & 16 & 0 & 0 & 0 & 0 & 12 & 8 \\
\hline
\end{tabular}


Based on Table 2, it can be observed that the company's most-supplied products include fruits such as watermelon (238 deliveries in 2017 and 149 in 2018), peach (220 in 2017 and 109 in 2018) and grapes (209 in 2017 and 167 in 2018). In the case of vegetables, the most significant supply in the analyzed period was paprika (143 deliveries in 2017 and 22 in 2018) and tomato (124 in 2017 and 109 in 2018). As in the case of the number of deliveries taking into account the countries of origin of products, there are visible deviations in the number of deliveries carried out in individual months for particular fruit and vegetables.

In order to clearly determine the factors causing such a phenomenon, the number of deliveries in May-October 2017 and May-October 2018 was analyzed for one of the most frequently supplied products by the company, which is watermelon (Figure 5). It is also one of the most popular fruits of the summer season.

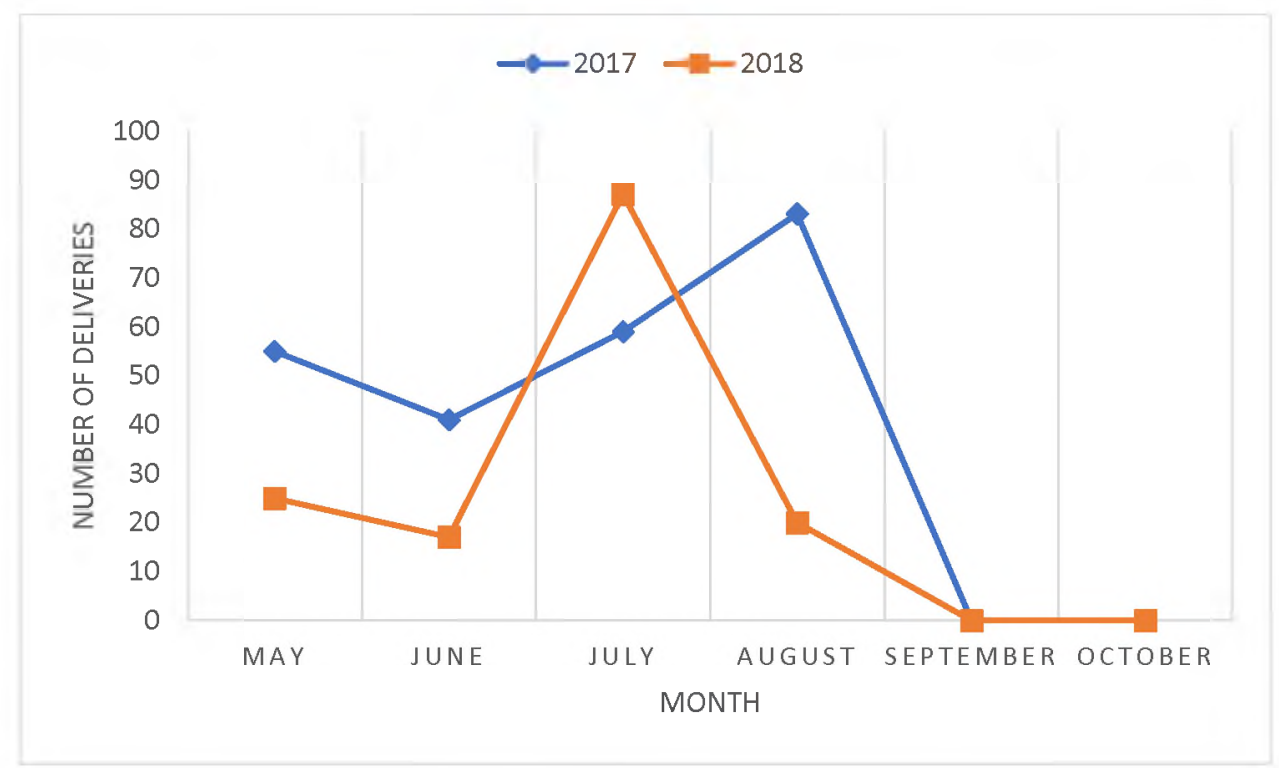

Fig. 5. The number of deliveries of watermelon in May-October 2017 and May-October 2018 periods Source: own work

Based on Figure 5, irregularities can be observed in the number of watermelon deliveries in the years 2017 and 2018. The largest number falls on July (in case of the year 2017) and August (in 2018). In months such as September or October, these products were not imported at all (the number of deliveries is 0 ). Noting that the largest harvest of watermelons in their countries of origin (e.g. Italy, Spain) coincides with the months in which their largest number of deliveries is carried out, it was determined that the factor affecting the irregularity of deliveries of watermelons (and fruit and vegetables in general) can be a phenomenon of seasonality of supply. 
The phenomenon of seasonality of supply is strictly associated with harvest periods of fresh fruit and vegetables which may be different for individual products. They could also be different depending on the country of origin of the product. In the case under study, the largest number of deliveries for all products (Figures 2 and 3) were in the May-August period, which may be due to the fact that most of the fruit and vegetables transported by the enterprise are then harvested (the season for them is going on).

Another factor causing the occurrence of the problem analyzed in the chapter may be, in addition to the above-mentioned seasonality of supply, seasonality of demand. The demand for the fresh fruit and vegetables can be larger when the season is for a given product, because then its price is lower.

In addition, there are many other factors that may have a significant impact on the seasonality of fresh fruit and vegetables, such as: weather conditions, economic factors, legal regulations, the level of competition. Apart from the species and number of transported fruit and vegetables, the proper organization of fresh fruit and vegetables transport is determined by: changing weather conditions, distances to which fruit and vegetables should be transported and their influence on the availability of particular raw materials on the market.

Knowing the factors which lead to the occurrence of the irregularity of deliveries, one can determine what actions can be taken in order to reduce it. In case of the analyzed enterprise, which deals mainly with the international transport, reducing the impact of seasonality of supply and demand of fresh fruit and vegetables on its functioning can be obtained by seeking new producers and consignees or expanding operations on the domestic market.

Based on the analysis of the problem related to the irregularity of deliveries, a general algorithm was proposed to improve the delivery process of fresh fruit and vegetables (Figure 6). 


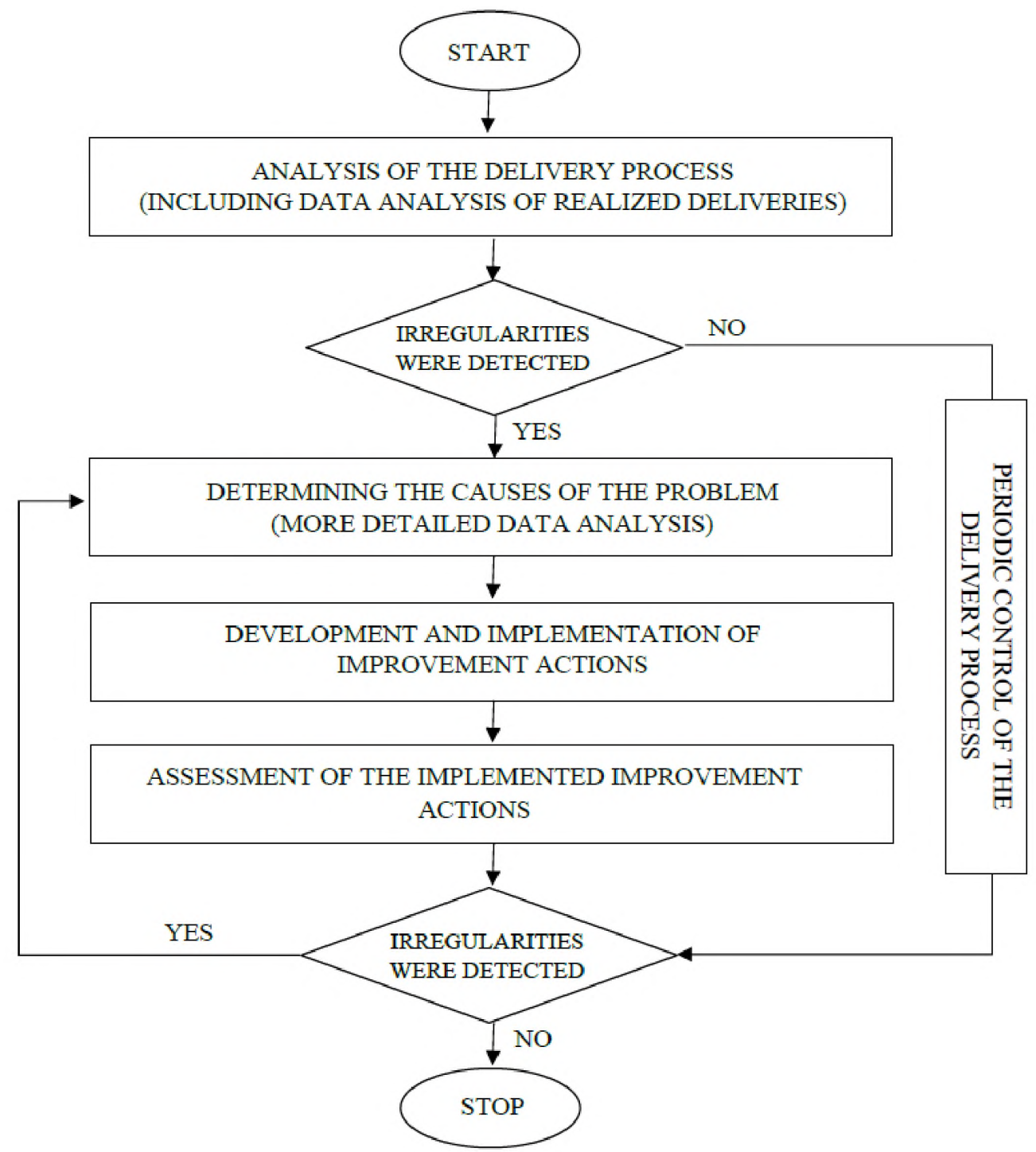

Fig. 6. Algorithm for the improvement of the delivery process of fresh fruit and vegetables Source: Own work

The process of improvement of the delivery process of fresh fruit and vegetables begins with the analysis of supply data, including, among others, their numbers. Then, there are two paths in the presented method, regarding whether there are any irregularities found thanks to the data analysis or not. The first path is as follows: when any irregularities are found, the next steps are the identification of the reasons for their occurrence and development and implementation remedial actions to reduce or eliminate the problem. Next, the assessment of the implemented improvement actions is performed. If during the check of the implemented improvements actions of the delivery process the irregularities were noticed, the causes of the problem must be reestablished. If they are not detected, the process is considered completed. The second path is 
related to not detecting any irregularities. To improve the quality of services it is necessary to constantly monitor the conducted activity, so in that case, the periodic control of the delivery process must be performed. If there are any disruption detected through this periodic control, the same actions as in the case of the first path must be taken. If there are not any irregularities, the process is assumed to be done. This type of algorithm may allow the improvement of the efficiency of an enterprise from the fresh fruit and vegetable transport sector. Moreover, it can also be used for deliveries of other types of products.

\section{CONCLUSION}

Transport of food products, especially fresh fruit and vegetables, is a real challenge for carriers. During the transport process, various types of conditions must be met for their carriage, including the selection of a proper mean of transport and right temperature inside the loading area. However, these are not the only problems that companies in this industry have to face. An additional issue occurring in this type of transport is the problem of the irregularity of deliveries.

In the chapter, this phenomenon was analyzed on the example of a selected enterprise. The analysis was based on the procedure consisting of the following stages: (1) definition of the problem, (2) detailed analysis of the delivery data, (3) determination of the causes of the examined problem and (4) proposing activities to eliminate the problem or reduce its occurrence. Thanks to the conducted research of this disturbance, it was determined that one of the most important factors affecting its occurrence is the seasonality of supply of individual fruit and vegetables. Another important factor was the seasonality of supply. When the factors affecting the occurrence of the irregularity of deliveries are known, it is essential to take measures to reduce or eliminate their impact on the operation of the enterprise. In the case of undertakings whose activity is focused primarily on the international transport of this type of products, the key is to look for new producers or expand their activities to the domestic country, in order to limit the impact of seasonality of supply and demand on the number of deliveries. It is also necessary to constantly monitor the number of deliveries made by the company and to put in place appropriate measures when a problem is detected once again. For this purpose, the authors proposed a general algorithm to improve the delivery process for fresh fruit and vegetables.

\section{ACKNOWLEDGEMENTS}

The publication was financed from the subsidy granted to the Cracow University of Economics. 


\section{REFERENCES}

Baran J., Sint A, 2014, Organizacja transportu w sektorze przetwórstwa świeżych owoców i warzyw, Logistyka, 4, 3479-3486.

Gajewska T., Lorenc A., 2019, The impact of environmental conditions on the quality of refrigerated food transport services - a case study, Transport Problems: an International Scientific Journal, 14(3), 97-107, DOI: 10.24136/atest.2019.13.

Gajewska, T., Grigoroudis, E. 2017, Estimating the performance of the logistics services attributes influencing customer satisfaction in the field of refrigerated transport, International Journal of Shipping and Transport Logistics, 9(5), 540-561, DOI: 10.1504/IJSTL.2017.086350.

Górecka-Orzechowska J., Raczek A., 2012, Transport świeżych owoców i warzyw w kontrolowanej atmosferze, Autobusy: technika, eksploatacja, systemy transportowe, 5, $192-$ 198.

Kuziemska B., Trębicka J., Pleniak-Lendzion K., 2016, Logistyka transportu w rolnictwie, Zeszyty Naukowe Uniwersytetu Przyrodniczo-Humanistycznego w Siedlcach, Seria: Administracja i Zarządzanie, Nr 109, 161-171.

Leleń P., 2015, Trendy zmian w organizacji transport w obrocie produktami żywnościowymi na przykładzie warzyw i owoców, Prace Naukowe Politechniki Warszawskiej, Z. 105, 6973.

Marczuk A., 2002, Logistyczne zarządzanie transportem truskawek, Acta Scienitarium Polonorum seria Technica Agraria, 1(2).

Satora M., Szkoda M., 2019, Zapewnienie jakości i bezpieczeństwa produktów żywnościowych w transporcie drogowym, Autobusy: technika, eksploatacja, systemy transportowe, 6, 8692, DOI: 10.24136/atest.2019.13.

Sobczyk G., 1976, Istota sezonowości produkcji, Annales Universitatis Mariae CurieSkłodowska, Sectio H, Oeconomia, 10, 169-182.

Tanner D., 2016, Food Quality, Storage, and Transport, 2016, Start Afresh Limited, Mounth Maunganui, New Zealand.

Umowa o międzynarodowych przewozach szybko psujących się artykułów żywnościowych i o specjalnych środkach transportu do tych przewozów (ATP) - Dz.U. z 2015 r., poz. 677.

A. Kolinski et al. (eds.), Contemporary challenges in supply chains, Vol. 1, https://doi.org/10.17270/B.M.978-83-66017-88-7.11 



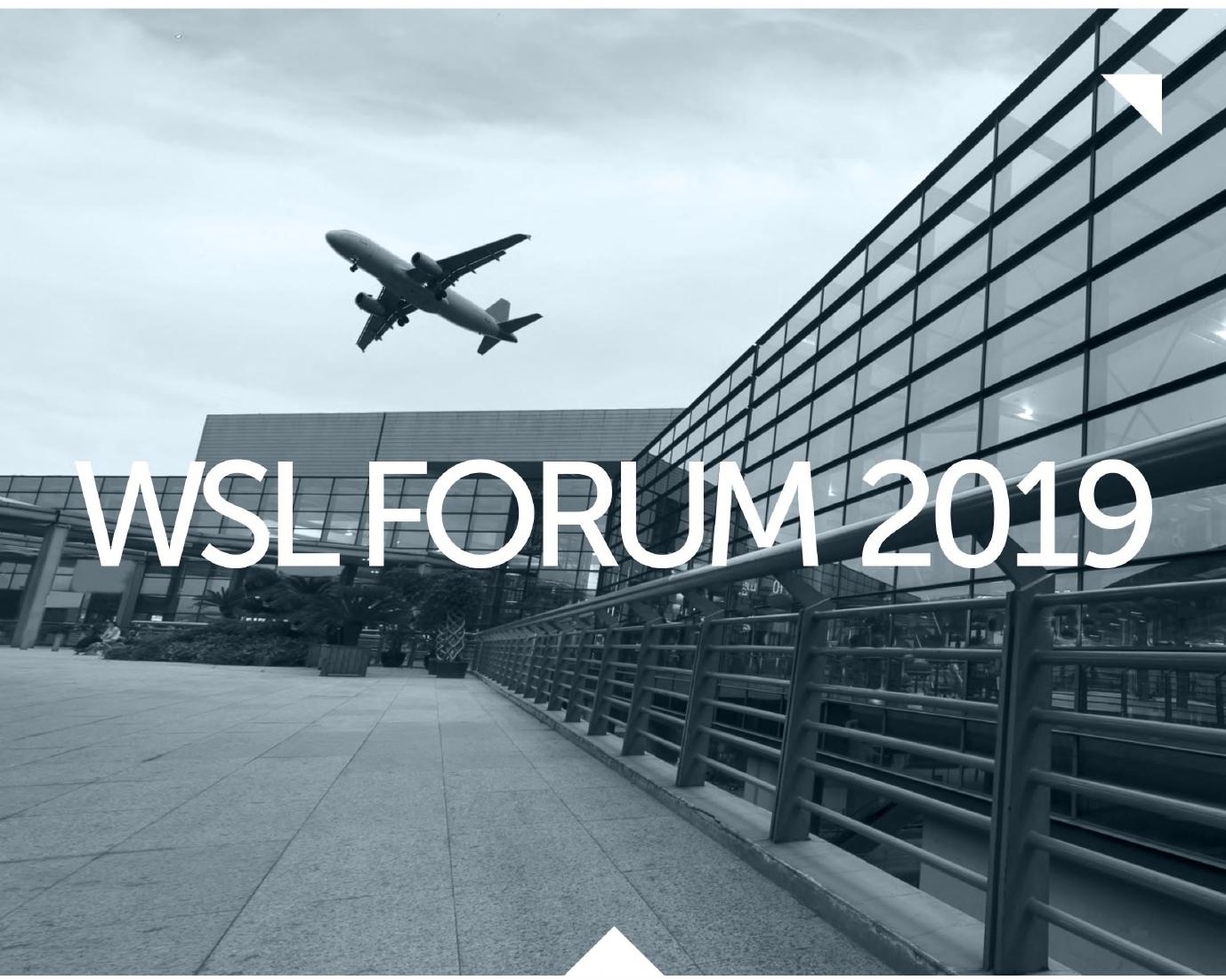

Papers included in this monograph was presented during WSLFORUM 2019 conference 18th - 19th of November 2019 in Poznan School of Logistics.
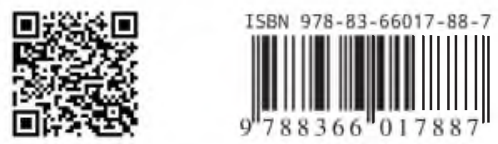